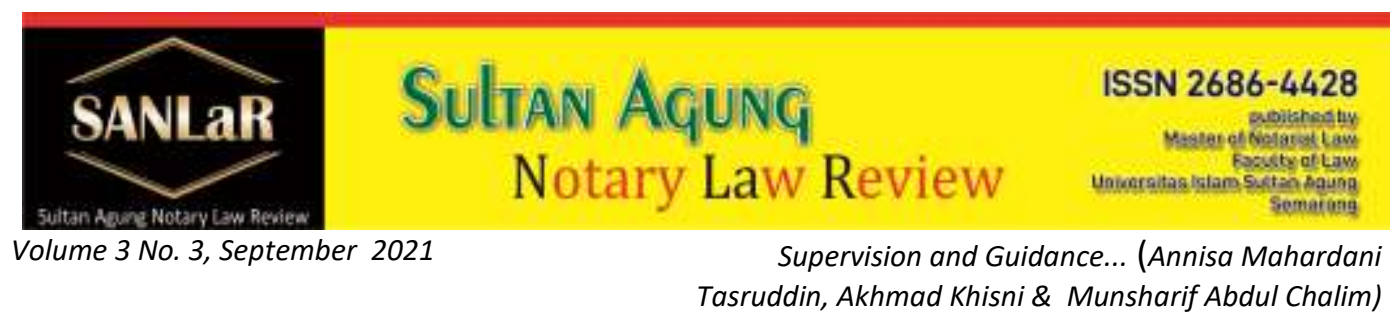

\title{
Supervision and Guidance Implementation on Notaries by Regional Supervisory Council \& Legal Consequences
}

\author{
Annisa Mahardani Tasruddin*, Akhmad Khisni** and Munsharif Abdul \\ Chalim***)
}

${ }^{*}$ Faculty of Law, Universitas Islam Sultan Agung (UNISSULA) Semarang, E-mail: mahardani41@gmail.com

${ }^{* *}$ Faculty of Law, Universitas Islam Sultan Agung (UNISSULA) Semarang, E-mail: khisni@unissula.ac.id

${ }^{* * *}$ Faculty of Law, Universitas Islam Sultan Agung (UNISSULA) Semarang, E-mail:
munsharifac@gmail.com

Abstract. The purpose of this study is to determine the implementation of Notary supervision carried out by MPD, the performance of Notaries based on the results of Notary supervision by MPD, and to find out the obstacles faced by MPD in carrying out Notary supervision in their area. The approach method in this research is normative juridical. The research specification is descriptive analytical. The data sources used in this study consist of primary data and secondary data which can be distinguished in primary legal materials, secondary legal materials, and tertiary legal materials. Collecting data in this study using the method of literature study and interviews. The data analysis technique used is the processed data which will be presented in the form of qualitative data analysis. Based on this research, it can be concluded that the Notary has the legal authority to make an authentic deed. In order to improve the quality and quantity of Notaries, a new regulation that applies to Notaries is issued, namely Act No. 30 of 2004 concerning Notary Positions (UUJN). Along with the accountability of the Notary to the community in carrying out his duties, then it must be guaranteed by the existence of a supervision and guidance. Notary supervision is carried out by involving several elements, namely experts from academics, government elements, and notary elements.

Keywords: Regional; Supervisory; Council; Guidance.

\section{Introduction}

Notaries are government employees who stand alone, are not paid by the government and receive honoraria from people who ask for their services. The 
Authentic Deed is the strongest and most complete evidence that has an important role in every legal relationship in people's lives, because the Authentic Deed clearly defines rights and obligations, guarantees legal certainty and is also expected to make a real contribution to the settlement of cases cheaply and quickly for the community. Therefore, what is stated in the Authentic Deed must be fully accepted by the parties, unless the interested party can prove the opposite satisfactorily in court. In the current era of globalization, notary institutions play an important role in every development process.

Because a Notary is a profession that exercises some state power in the field of private law and has an important role in making an Authentic Deed that has perfect evidentiary power and because the position of a Notary is a position of trust, a Notary must have good behavior. ${ }^{1}$ As a public official, a Notary acts solely for the benefit of the legal community to be served. ${ }^{2}$ Personally, the Notary is responsible for the quality of the services it provides. Because of the importance of the role and services of Notaries in the field of legal traffic, especially for legal actions in the field of civil law in people's lives, it is necessary to have continuous guidance and supervision of Notaries who carry out their duties so that Notary institutions run in accordance with ethical values and applicable law and avoid abuse of authority or trust given.

Notaries as public officials are one of the state organs equipped with legal authority to provide public services to the community, especially in making authentic deeds as perfect evidence regarding legal actions in the civil sector. ${ }^{3}$

Notary institutions are increasingly recognized by the public and are needed in making authentic written evidence of a legal act carried out by the community. The need for a notary institution in daily legal practice cannot be separated from the increasing level of the economy and legal awareness of the community. The power of an authentic deed made by a notary has a very strong legal force considering that an authentic deed is a perfect evidence. So it is not uncommon for various laws and regulations to require certain legal actions to be made in authentic deeds, such as the establishment of limited liability companies, cooperatives, fiduciary guarantee deeds and so on. In addition to the deed made at the request of the parties, Notaries and their deed products can be interpreted as state efforts to create legal certainty and protection for members of the public. Bearing in mind that in the private/civil law area, the state places a

\footnotetext{
${ }^{1}$ Liliana Tedjosaputro. Etika Profesi Notaris Dalam Penegakan Hukum Pidana. (Yogyakarta: Bigraf Publishing, 1994). p.5.

${ }^{2}$ Henricus Subekti, Tugas Notaris (Perlu) Diawasi, Majalah Renvoi Nomor 11.35.III, April 32006 Edition, p. 40.

${ }^{3}$ N.G. Yudara, 2006, Notaris dan Permasalahannya (Pokok-Pokok Pemikiran Di Seputar Kedudukan Dan Fungsi Notaris Serta Akta Notaris Menurut Sistem Hukum Indonesia), Makalah disampaikan dalam rangka Kongres INI di Jakarta: Majalah Renvoi Nomor 10.34.III, p. 72.
} 
notary as a public official who is authorized in terms of making an authentic deed, for the sake of proof/evidence.

Along with the accountability of the Notary to the community in carrying out his duties, it must be guaranteed by the existence of continuous supervision and guidance by other parties so that the duties and authorities of the Notary are always in accordance with the legal rules that underlie their authority and can avoid abuse of authority or trust given by the notary, government and society.

In Act No. 30 of 2004, State Gazette Number 117, Supplement to the State Gazette Number 4432 concerning Notary Positions (UUJN), it is determined that the Supervisory Agency authorized to carry out the functions of supervision and development is called the Notary Supervisory Council (MPN).

The Notary Supervisory Council is not only authorized to supervise and examine Notaries, but also has the authority to impose certain sanctions on Notaries who have been proven to have violated the law against the Notary Position regulations. ${ }^{4}$

Supervision of notaries is important so that in carrying out their duties and positions, notaries can uphold the dignity of their positions. Based on Act No. 2 of 2014 concerning Amendments to Act No. 30 of 2004 concerning the Position of a Notary, hereinafter referred to as UUJN. Article 1 point 1 UUJN explains that "Notaries are public officials authorized to make authentic deeds and other authorities as intended in this law or based on other laws".

Basically, the role of a notary is to provide services in the form of services for people who intend to make authentic evidence. Service here should not be interpreted narrowly, as "making a deed" only. Service must be interpreted regarding holistic and comprehensive aspects, starting from the convenience of the public in getting information, contacting the Notary, coming to the Notary's place, Notary office facilities, the friendliness of the Notary and his employees, and so on. Making a deed is only part of the activity called service.

The above is closely related to the large number of Notaries in Indonesia at this time, so it cannot be denied that it creates competition among Notaries. However, this competition should not always be viewed from a negative perspective, but should be a "whip" for every Notary to improve his services.

Services in the notary world cannot be equated with services in the ordinary business world because services in the notarial world must still refer to and

${ }^{4} \mathrm{Habib}$ Adjie, 2005, Undang-Undang Jabatan Notaris (UUJN) sebagai Unifikasi Hukum Pengaturan Notaris, Renvoi, No. 28, p. 130. 
comply with the Notary Code of Ethics which has been ratified and agreed upon in Act No. 30 of 2004 junto Act No. 2 of 2014 concerning Positions Notary (hereinafter referred to as UUJN), so that a Notary who provides services to his clients may not sacrifice the nobility and dignity of the Notary as a public official.

Notaries as one of the bearers of the legal profession are people who have expertise and knowledge in the notarial field, so that they are able to meet the needs of the community who need services in the notarial field. ${ }^{5}$

It is possible that in notarial services, abuse of authority is found, or notaries who are not subject to and obedient to the notary code of ethics and the Law on Notary Positions, and with the above possibilities, a form of supervision is needed and even preventive and continuously to the notary. Since the presence of the notary institution in Indonesia, supervision of the notary has always been carried out by the judiciary and the government. The purpose of supervision is that Notaries when carrying out their duties fulfill all requirements related to the implementation of the duties of a Notary, in order to safeguard the interests of the community. Prior to the enactment of the UUJN, supervision, examination, and imposition of sanctions on Notaries were carried out by the judiciary.

After the enactment of the UUJN, the judiciary no longer supervises, examines, and imposes sanctions on Notaries, this authority is exercised by the Minister of Law and Human Rights by establishing a Notary Supervisory Council. This is in accordance with Article 67 paragraph 1 of the Law on Notary Positions which reads "Supervision of Notaries is carried out by the Minister and Article 67 paragraph 2 of the Notary Position Law which reads "in carrying out the supervision as referred to in paragraph 1, the Minister shall establish a Supervisory Council".

Public officials are defined as officials who are entrusted with the task of making authentic deeds that serve the public interest, and such qualifications are given to a notary. Thus, a notary is a public official who has the authority to make an authentic deed regarding all acts of agreement and provisions required by legislation and/or desired by the interested parties. To ensure the rights and obligations of the parties for the sake of certainty, order, and legal protection for the interested parties as well as for the community as a whole so that it is expected to avoid disputes. In the event of a dispute, the authentic deed which is the strongest and most complete evidence can provide the best solution for the settlement of the case cheaply and quickly.

${ }^{5}$ Khotib. 2008. Kode Etik Notaris Indonesia, Materi Kode Etik Notaris, tersedia : http://khotibwriteinc.blogspot.com/2008/03/kode-etik-notaris-indonesia.html, accessed on 5 June 2021 
Notaries in carrying out their positions are appointed by the competent government based on law, every act of this government is required to be based on legal authority. In state administrative law, the basis for the government to carry out public legal acts is the existence of a position. Positions obtain authority through three sources, namely attribution, delegation, and mandate. These three sources of authority will give birth to authority (bevoeg dheid, legal power, competence) $)^{6}$.

Based on the perspective of the source of authority, notaries have attributive authority granted by lawmakers, through Act No. 2 of 2014 concerning amendments to Act No. 30 of 2004 concerning Notary Positions. So that the notary has the legality to carry out legal actions to make an authentic deed.

In Article 2 of Act No. 30 of 2004 concerning the Position of a Notary, a notary is appointed and dismissed by the Minister, in this case the minister whose duties and responsibilities include the Notary field. In addition, the Law on Notary Positions stipulates that the minister carries out supervision which is given in the form of legislative delegation to the minister to form a Notary Supervisory Council. The delegation of authority is carried out through a decision of the Minister to his subordinate officials, namely the Director General or the head of the Regional Office to sign on behalf of the Minister to form a Supervisory Council.

Article 1 number 6 of the UUJN explains that the Notary Supervisory Council is a body that has the authority and obligation to carry out guidance and supervision of Notaries.

The purpose of the guidance and supervision of a Notary is so that the Notary seriously fulfills the requirements and carries out his duties in accordance with the provisions of the applicable legislation. Mechanism of guidance and supervision of Notaries in carrying out their duties and positions.

\section{Research Methods}

This approach method uses the normative juridical method, this research based on its nature is a descriptive analytical research.

\footnotetext{
${ }^{6}$ A Chuasanga, Ong Argo Victoria. (2019). Legal Principles Under Criminal Law in Indonesia Dan Thailand, Jurnal Daulat Hukum, Vol 2, No 1 (2019) http://jurnal.unissula.ac.id/index.php/RH/article/view/4218, see Deen, Thaufiq., Ong Argo Victoria \& Sumain. (2018). Public Notary Services In Malaysia. JURNAL AKTA: Vol. 5, No. 4, 10171026. Retrieved from http://jurnal.unissula.ac.id/index.php/akta/article/view/4135
} 


\section{Results and Discussion}

\subsection{Analysis of the Implementation of Notary Guidance and Supervision by the Kolaka City MPD}

The work program of the Kolaka City MPD is to carry out one of the duties and authorities of the Supervisory Council, namely the examination of the Notary protocol. For the purposes of routine inspections (once a year) as well as certain times as needed, the MPD of Kolaka City has formed an Examining Team consisting of three people from each element, assisted by one secretary.

The MPD work procedure is regulated in Article 15 of the Ministerial Regulation no. M.02.PR.08.10 Of 2004, among others seven working days before the examination is conducted, the Notary concerned shall be given a written notification no later than 7 (seven) working days before the examination is conducted, which includes the hours, days and dates of the examination as well as the composition of the Examining Team. . At the time the examination is carried out, the Notary concerned must be in his office and prepare all the protocols to be examined, which consist of:

a. Minutes of deed;

b. Register of deeds or reportorium;

c. A special book for registering private letters that are ratified by their signatures and privately recorded letters;

d. The list of names of the appearers or klapper from the list of legalized deeds and registered letters;

e. Protest register book;

f. will register book; and

g. Other register books that must be kept by a Notary based on the provisions of laws and regulations.

The Examining Team must also check, among others:

a. Notary office conditions;

b. Letter of appointment as Notary and Official Oath of Office;

c. Notary leave permit certificate and Notary leave certificate;

d. Archive state;

e. State of deed storage;

f. Monthly report;

g. Pick-up test on the deed;

h. Number of employees, and;

i. Office facilities. 
In addition, the Examining Team records in the register book and the bundle of minutes of deeds included in the Notary protocol by mentioning the date of examination, the number of deeds and the number of private documents that were legalized and made since the date of the last examination. The foregoing matters are as regulated in Part $\mathrm{V}$ of the Ministerial Decree Number M.39PW.07.10 of 2004. Furthermore, the Examining Team shall prepare a Minutes of Examination signed by the chairman and the Notary concerned, at least in five copies for the purposes of the MPD itself, MPW, MPP, INI Regional Management and the Notary concerned, as regulated in Article 17 of the Ministerial Regulation Number M.02.PR.08.10 of 2004.

The results of the examination by the Examining Team contained in the Minutes of Examination are evaluated to assess the level of compliance of the Notary with the UUJN and the Notary Code of Ethics, and the results of the evaluation are taken into consideration in conducting guidance and supervision of the Notary.

To achieve an ideal coaching and supervision practice, in principle, coaching and supervision is very dependent on how the coaching and supervision is carried out. In other words, the implementation of supervision must be adjusted to the needs and objectives to be achieved through these activities. Therefore, the steps taken by the Notary Supervisory Board in conducting guidance and supervision must be carefully thought out, and carefully so that they are right on target.

\subsection{Constraints faced by MPD in Implementing Supervision and Guidance on Notaries}

There are several factors inhibiting the implementation of guidance and supervision by the Kolaka City MPD against Notaries in Kolaka City which resulted in the non-execution of the Notary MPD authority in Article 70 and Article 71 of the UUJN, Article 13 paragraph (1) and paragraph (2) of Ministerial Regulation Number M.02 .PR08.10 and Part III Number 1.2. Ministerial Decree Number: M.39-PW.07.10 of 2004, Article 8 paragraph 1, Article 9 to Article 11, Article 14 to Article 18 of Ministerial Regulation Number: M.03.HT.03.10 of 2007, Article 4 of the Notary Code of Ethics is ;

1. The limited funds used by the Kolaka City Notary MPD to provide guidance and supervision because the funds that should have been provided by the Regional Office of the Ministry of Law and Human Rights of the Republic of Indonesia, Southeast Sulawesi, were not sufficient.

2. The busyness of each member of the Notary MPD of Kolaka City doing their main work, namely as a lecturer, as a Notary or who works as a Civil Servant in each related institution. 
3. Each member of the Kolaka City Notary MPD does not have a vision and program.

4. There is still a lack of implementing regulations for UUJN in relation to the guidance and supervision carried out by the Notary Supervisory Council.

In accordance with the provisions of Article 3 paragraph 11 of the Notary Code of Ethics, each INI member is required to pay dues in an orderly manner, while there are no regulations in either the UUJN or its implementing regulations that require Notaries to pay dues to the MPD, because the Notary Supervisory Board was formed by the Minister to implement Notary supervision so that the funds issued in connection with the implementation of the supervision are channeled by the Ministry of Law and Human Rights of the Republic of Indonesia, in the case of the Kolaka City MPD the funds are provided by the Regional Office of the Ministry of Law and Human Rights of the Republic of Indonesia, Southeast Sulawesi. Therefore, it is not appropriate if the issue of Notary fees to MPD Kolaka becomes one of the obstacles in implementing the guidance and supervision of Notaries in Kolaka City.

In connection with the busyness of each member of the Kolaka City MPD doing their main work, so that communication between members is not good where it becomes one of the obstacles to the implementation of guidance and supervision of Notaries in Kolaka City, this should not need to happen, because everyone who receives the proposed appointment of him as a member of the MPD from each element (government, notary organizations and academics) should be able to manage their respective times in carrying out their work and be responsible for carrying out the duties and positions they carry as members of the MPD.

\section{Closing}

The efforts to develop and supervise Notaries, MPD Kolaka City refers to Article 1 paragraph (5) of the Ministerial Regulation Number M.02.PR.08.10 of 2004 that supervision is a preventive and curative activity, including development activities for Notaries in the region of his authority. Where preventive activities are carried out are activities that include administrative authorities, for example activities that regulate more procedural procedures and notarial protocols. Meanwhile, the curative activities carried out are activities related to the regulations governing the taking of action against alleged violations committed by a Notary against the UUJN and the Code of Ethics. The results of the examination by the Examining Team contained in the Minutes of Examination are evaluated to assess the level of compliance of the Notary with the UUJN and the Notary Code of Ethics, and the results of the evaluation are taken into consideration in conducting guidance and supervision of the Notary. 


\section{References}

Journals:

[1] A Chuasanga, Ong Argo Victoria. (2019). Legal Principles Under Criminal Law in Indonesia Dan Thailand, Jurnal Daulat Hukum, Vol 2, No 1 (2019) http://jurnal.unissula.ac.id/index.php/RH/article/view/4218

[2] Deen, Thaufiq., Ong Argo Victoria \& Sumain. (2018). Public Notary Services In Malaysia. JURNAL AKTA: Vol. 5, No. 4, 1017-1026. Retrieved from http://jurnal.unissula.ac.id/index.php/akta/article/view/4135

Books:

[1] Asthofa, Burhan. Metode Penelitian Hukum. Jakarta: Rineka Bakti, 2004.

[2] Brotosusilo, Agus dan Jufrina Rizal. Filsafat Hukum. Jakarta: Program Pasca Sarjana Universitas Indonesia, 2004.

[3] Fatahna, Muclis dan Purwanto Joko. Notaris Bicara Soal Kenegaraan. Jakarta: Watampone Press, 2003.

[4] Habib, Adjie. Tebaran Pemikiran Dalam Dunia Notaris Dan PPAT "Penegakan Etika Profesi Notaris Dari Prespektif Pendekatan Sistem". Lembaga Kajian Notaris dan PPAT Indonesia. Surabaya, 2003.

[5] Sanksi Perdata dan Administritif Terhadap Notaris Sebagai Pejabat Publik, Bandung: PT. Refika Aditama, 2008.

\section{Regulations:}

[1] Act No. 30 of 2004 on Notary Positions, State Gazette No. 117, Supplement to the State Gazette No. 4432.

[2] Decree of the Minister of Law and Human Rights of the Republic of Indonesia concerning Guidelines for the Implementation of the Duties of the Notary Supervisory Council. Ministerial Decree No: M.39-PW.07.10 Of 2004

[3] Ministry of Justice and Human Rights of the Republic of Indonesia. Decree of the Minister of Justice and Human Rights of the Republic of Indonesia concerning Notary. Ministerial Decree No: M OL.HT03.01 of 2003. 